\title{
ASUHAN KEBIDANAN PADA IBU HAMIL DENGAN EMESIS GRAVIDARUM DI PMB ERNITA PEKANBARU TAHUN 2020
}

\author{
Yulrina Ardhiyanti, Vivin Wulandari \\ STIKes HANG TUAH PEKANBARU
}

\begin{abstract}
Emesis gravidarum is usually characterized by nausea and vomiting and can cause various adverse effects, one of which is a decrease in appetite. The impact on the fetus is that the fetus will lack the nutrients and fluids needed by the body. At PMB Ernita in January 2020 there were 4 out of 10 pregnant women who experienced emesis gravidarum. The goal of care is to provide obstetric care for pregnant women with emesis gravidarum. The method used was a case study conducted at PMB Ernita from 31 August 04 September 2020 with the criteria for a pregnant woman in the first trimester with nause and vomiting. The care used was consuming sugarcane juice combined with ginger water which was drunk 3 times a day for 4 days then followed by a home visit for 4 days on 31 August - 04 September 2020. The development of the midwifery care that was given to the patient Mrs.R with consuming sugarcane juice combined with ginger boiled water as much as $330 \mathrm{ml} 3$ times a day for 4 days was successful because the nausea and vomiting were reduced. And it is hoped that PMB Ernita can provide leaflets or brochures so that pregnant women can read about emesis gravidarum and the care given by the therapy of boiled ginger water combined with sugarcane juice.
\end{abstract}

Keyword : Midwifery Care, Emesis Gravidarum, Pregnant Women

\begin{abstract}
ABSTRAK
Emesis gravidarum biasanya ditandai dengan mual muntah dan dapat menimbulkan berbagai dampak buruk salah satunya penurunan nafsu makan. Dampak bagi janin adalah janin akan kekurangan nutrisi dan cairan yang dibutuhkan oleh tubuh. Di PMB Ernita pada bulan Januari 2020 terdapat sebanyak 4 orang dari 10 ibu hamil yang mengalami emesis gravidarum. Tujuannya untuk melakukan asuhan kebidanan pada ibu hamil dengan emesis gravidarum. Metode yang digunakan adalah studi kasus yang dilaksanakan di PMB Ernita dari tanggal 31 Agustus-04 September 2020 dengan kriteria pasien ibu hamil trimester I dengan mual muntah. Asuhan yang diberikan adalah mengkonsumsi terapi air tebu dikombinasikan dengan air jahe yang diminum 3 kali sehari selama 4 hari kemudian dilanjutkan dengan kunjungan rumah selama 4 hari pada tanggal 31 Agustus - 04 September 2020. Perkembangan dari asuhan kebidanan yang di berikan pada pasien Ny.R dengan mengkonsumsi terapi air tebu dikombinasikan dengan air rebusan jahe sebanyak $330 \mathrm{ml} 3$ x sehari selama 4 hari berhasil karena mual muntah berkurang.Diharapkan PMB Ernita agar dapat menyediakan leaflet atau brosur agar ibu hamil bisa membaca tentang emesis gravidarum dan asuhan yang diberikan dengan terapi air rebusan jahe dikombinasikan dengan air tebu.
\end{abstract}

Kata Kunci : Asuhan Kebidanan, Emesis Gravidarum, Ibu Hamil 


\section{PENDAHULUAN}

Emesis gravidarum merupakan salah satu tanda dan gejala kehamilan yang umum terjadi pada ibu hamil pada awal kehamilan trimester I. Emesis gravidarum biasanya ditandai dengan mual muntah saat hamil muda pada beberapa kasus dapat berlanjut sampai kehamilan trimester kedua dan ketiga tapi itu jarang terjadi (Pudiastuti, 2012).

Angka kejadian emesis gravidarum sedikitnya $15 \%$ dari semua wanita hamil (WHO, 2015). Angka kejadian emesis gravidarum di Indonesia yang didapatkan dari 2.203 kehamilan yang dapat diobservasi secara lengkap adalah 543 orang ibu hamil yang terkena emesis gravidarum.Di Indonesia sekitar 10\% wanita hamil yang terkena emesis gravidarum. Di Riau kejadian emesis gravidarum sebanyak 10\% - 15\% dari jumlah ibu hamil sebanyak 182.815 pada tahun 2015 (Depkes, 2015).

Menurut penelitian Wardani (2020), obat nonfarmakologi / terapi dengan air tebu dikombinasi dengan air rebusan jahe bisa mengurangi mual muntah pada pasien emesis gravidarum. Dalam penelitian ini menunjukkan bahwa air tebu dikombinasikan dengan air rebusan jahe dapat menghilangkan mual muntah pada ibu emesis gravidarum.Cara mengkonsumsi air tebu dikombinasikan dengan rebusan air jahe yaitu dianjurkan untuk mengkonsumsi $100 \mathrm{ml}$ air tebu dan $10 \mathrm{ml}$ air jahe yang diminum 3 kali sehari selama 4 hari untuk mengurangi mual muntah pada ibu emesis gravidarum.

Berdasarkan wawancara pada ibu hamil yang dilakukan di PMB Ernita di bulan Januari 2020, dari 10 orang ibu hamil terdapat 4 orang yang mengalami emesis gravidarum Upaya bidan tersebut untuk mengatasi pasien emesis gravidarum adalah konseling dan memberikan obat.

\section{METODE}

Studi kasus ini menggunakan metode deskriptif observasional dengan pendekatan Continuity of care diberikan pada ibu hamil dengan emesis gravidarum di PMB Ernita Pekanbaru yang beralamat di Jalan Lobak No.115 Delima, Kecamatan Tampan, Kota Pekanbaru. Asuhan diberikan pada Ny. P dengan 2 kali kunjungan adalah mengkonsumsi air tebu dikombinasikan dengan air jahe yang diminum 3 kali sehari selama 4 hari pada tanggal 31 Agustus-04 September 2020.

Cara pengumpulan data anamnesa, observasi, pemeriksaan dan dokumentasi. Analisa data dengan membandingkan antara data yang diperoleh dengan teori yang ada. 
HASIL

\section{Kunjungan I}

Kunjungan pertama ini dilakukan pada tanggal 31 Agustus 2020 pukul 10.00 WIB. Kunjungan antenatal dilakukan dirumah pasien yang beralamat di Jalan Teropong Arengka.

\section{a. Data Subjektif}

Ibu mengatakan berusia 19 tahun, bekerja sebagai ibu rumah tangga, mengatakan ini kehamilan yang kedua, yang pertama keguguran karena terjatuh dari kamar mandi, HPHT 2305-2020, mual muntah setiap pagi dan malam dan setiap habis makan kurang lebih 2 sampai 3 kali. Ibu masih bisa mengerjakan pekerjaan rumah. Ibu mengatakan hasil USG janinnya masih kecil harus ditambahi berat badannya dan ada permasalahan. Ibu tidak memiliki riwayat penyakit yang pernah diderita.

\section{b. Data Objektif}

Keadaan umum ibu baik dan kesadaram composmentis, Tekanan Darah : 110 / 70 mmHg, Denyut Nadi : $82 \mathrm{x} /$ menit, Pernafasan : 20x/menit, Suhu : $36,8{ }^{\circ} \mathrm{C}, \mathrm{BB}$ sebelum hamil : 50 $\mathrm{kg}$, BB sekarang : $48 \mathrm{~kg}$, Tinggi badan : $160 \mathrm{~kg}$, Lila : $27 \mathrm{~cm}$, kelopak mata ibu tidak pucat, konjungtiva merah muda, putting susu menonjol, ibu tidak ada merasakan benjolan maupun rasa nyeri, kebersihan baik, hasil palpasi TFU : 2-3 jari diatas simpisis.

\section{c. Assasment}

G2 P0 A1 Usia kehamilan 14 minggu 2 hari dengan Emesis Gravidarum

d. Plan

Informasi, edukasi, dan terapi :

1) Hasil pemeriksaan

2) Pendidikan kesehatan tentang emesis gravidarum

3) Beberapa hal yang bisa dilakukan oleh ibu hamil emesis gravidarum

4) Pendidikan tentang kesehatan tentang nutrisi

5) Tanda-tanda bahaya kehamilan

6) Penanganan Terapi Herbal Untuk Emesis Gravidarum

7) Kunjungan ulang

\section{Kunjungan II}

Pada kajian ini merupakan hasil dari kunjungan antenatal kedua yang dilakukan pada tanggal 04 september 2020. Data yang dikumpulkan hanya fokus pada pemeriksaan khusus kehamilan yaitu dengan keluhan mual muntah atau emesis gravidarum.

\section{a. Data subjektif}

1) Ibu mengatakan mual muntahnya sudah mulai berkurang selepas minum air terapi. 
2) Ibu mengatakan muntahnya hanya dipagi hari dan malam hari sudah jarang

\section{b. Data objektif}

1) Keadaan umum ibu baik dan kesadaran composmentis

2) Tanda - tanda vital : Tekanan darah : $100 / 90 \mathrm{mmHg}$

Denyut nadi $\quad: 80 \mathrm{x} / \mathrm{menit}$

Pernafasan : $20 \mathrm{x} / \mathrm{menit}$

Suhu $\quad: 36,6^{\circ} \mathrm{C}$

\section{c. Assasment}

G2P0A1 Usia kehamilan 15 minggu dengan emesis gravidarum

\section{d. Plan}

Informasi , edukasi dan terapi :

1) Hasil pemeriksaan

2) Kondisi mual muntah

3) Penkes asupan nutrisi

4) Kunjungan ulang

\section{PEMBAHASAN}

Pembahasan ini ditulis dengan memberikan penjelasan khusus mengenai tinjauan kasus yang telah dijabarkan agar didapatkan suatu pemecahan masalah dari kesenjangan yang ada diawal dan diakhirnya dapat di tarik kesimpulan sehingga dapat digunakan sebagai tinda lanjut dalam penerapan asuhan kebidanan yang tepat, efektif serta efisien.Pembahasan ini dibahas setiap kajian dari kunjungan yang pertama sampai kunjungan ke dua pada tanggal 31
Agustus 2020 - 04 September 2020 serta mengevaluasi hasil dari kunjungan tersebut.

\section{a. Data Subjektif}

Berdasarkan hasil kunjunngan pertama Ny. P, pada tanggan 31 Agustus 2020 jam 10.00 WIB ibu mengatakan saat ini mual muntah ibu tidak tertahankan Karena setiap pagi, habis makan dan malam selalu muntah. Muntahnya sekitar 3 kali dalam sehari.Pada kunjungan ke dua ibu mengatakan mual muntahnya sudah mulai berkurang.

Perbedaan tingkatan mual muntah yang sering dijumpai adalah morning sickness, emesis gravidarum dan hiperemesis gravidarum. Emesis gravidarum ini mual muntah beberapa kali terutama pada pagi hari, tidak menyebabkan gangguan aktivitas sehari hari.(Manuaba, 2010)

Emesis gravidarum merupakan hal yang fisilogis tetapi apabila tidak segera diatasi akan menjadi hal yang patologis. Rasa mual biasanya dimulai dari minggu pertama kehamilan dan berakhir pada minggu keempat. Selain itu emesis gravidarum memberikan dampak secara fisologis , social, dan spiritual. Secara psikologis emesis gravidarum dapat menimbulkan kecemasan, rasa bersalah, dan marah jika gejala mual muntah semakin berat. Selain itu dapat terjadi konflik antara ketergantungan terhadap 
pasangan dan kehilangan kontrol jika ibu sampai berhenti berkerja (Runiari, 2010).

Dari hasil asuhan yang telah diberikan selama 4 hari didapatkan hasil dari ibu bahwa mual muntahnya berkurang dikarenakan ibu minum air terapi tebu dikombinasikan dengan rebusan jahe.Karena jahe mengandung minyak atsiri sebagai anti anflamasi sehingga jahe dapat mengurangi frekuensi mual muntah pada ibu hamil sehingga menganjurkan ibu untuk mengkonsumsi air tebu dikombinasikan dengan air jahe untuk menetralisirkan mual dan muntah pada ibu hamil dengan diberikan 3 kali sehari selama 4 hari.Dan pada kunjungan ke 2 tanggal 04 September 2020 ibu mengatakan mual muntahnya mulai berkurang.

\section{b. Data Objektif}

Dari hasil pemeriksaan kunjungan pertama pada tanggal 31 Agustus 2020 yaitu Keadaan umum ibu baik dan kesadaran composmentis, Tekanan darah : 110 / $70 \mathrm{mmHg}$, Denyut nadi : 82 x/menit, Pernafasan : $20 \mathrm{x} / \mathrm{menit}$, Suhu : $36,8{ }^{\circ} \mathrm{C}$, BB sebelum hamil : $50 \mathrm{~kg}$, BB sekarang : $48 \mathrm{~kg}$, Tinggi badan : $160 \mathrm{~kg}$, Lila : 27 $\mathrm{cm}$, kelopak mata ibu tidak pucat, konjungtiva merah muda, putting susu menonjol, ibu tidak ada merasakan benjolan maupun rasa nyeri, kebersihan baik, hasil palpasi TFU : $2-3$ jari diatas simpisis.
Menurut (Maulana, 2013), beberapa nutrisi pada ibu hamil dengan emesis gravidarum yaitu makan dalam jumlah sedikit tetapi sering, makan makanan yang mengandung karbohidrat dan protein yang dapat membantu mengatasi rasa mual. Banyak mengonsumsi buah, sayuran dan makanan yang mengadung tinggi karbohidrat seperti roti, kentang, biscuit dan sebagainya, hindari makanan yang berlemak, berminyak, dan pedas yang akan memperburuk rasa mual, minum yang cukup untuk menghindari dehidrasi akibat muntah dan hindari minuman yang mengandung kafein, vitamin B6 efektif untuk mengurangi rasa mual pada ibu hamil. Pemakaian ini juga membutuhkan konsultasi dari dokter, Pengobatan tradisional seperti jahe dan lemon dapat mengurangi rasa mual, makan makanan yang mengandung lemak dan protein yang rendah seperti ikan, ayam tanpa kulit, telur dan sebagainya

\section{c. Assessment}

Assessment pada kasus ini sesuai dengan teori menurut (Megasari et al., 2019) penilaian yang dilakukan akan berujung pada kesimpulan kondisi klien yang harus ditindaklanjuti yang bertuang dalam plan atau rencana asuhan yang diberikan. Assessment yang dapat ditegakkan pada asuhan kebidanan kajian I adalah G2P0A1 usia kehamilan 14 minggu 2 hari dengan Emesis 
Gravidarum. Assessment yang dapat di tegakkan pada asuhan kebidanan kajian II adalah G2P0A1 usia kehamilan 15 minggu dengan Emesis Gravidarum.

\section{d. Plan}

Pada saat asuhan kunjungan pertama ibu dianjurkan untuk mengkonsumsi terapi air tebu dikombinasikan dengan rebusan jahe 3 x sehari sebanyak $330 \mathrm{ml}$ perhari selama 4 hari.Pada kunjungan kedua terlihat mual muntah ibu berkurang dan tetap menganjurkan ibu minum terapi air tebu dikombinasikan dengan air jahe.

Jahe baik untuk ibu hamil dengan porsi yang cukup karena jahe Obat alami saat terasa mual, muntah maupun mabuk perjalanan. Menurut sebuah penelitian(Redi Aryanta, 2019), jahe sangat efektif untuk mencegah dan menghindarkan seseorang dari berbagai keluhan kesehatan seperti mual, muntah serta mabuk saat perjalanan.

Dari hasil penelitian yang dilakukan (Wardani, 2020) diketahui bahwa rata-rata Emesis Gravidarum pada ibu hamil di Wilayah Kerja Puskesmas Rawat Inap Sidomulyo Pekanbaru sebanyak 5.87 kali sebelum mengkonsumsi air tebu kombinasi dengan air jahe dan mengalami penurunan menjadi 0.47 kali sesudah mengkonsumsi air tebu kombinasi dengan air jahe. Dalam penelitian ini air tebu dikombinasikan dengan air rebusan jahe ini diberikan kepada ibu hamil dengan emesis gravidarum selama 4 hari frekuensi pemberian $3 \mathrm{kali} / \mathrm{hari}$.

Menurut penulis bahwa kandungan yang terdapat pada jahe iyalah minyak atsiri sebagai anti anflamasi sehingga jahe dapat mengurangi frekuensi mual muntah pada ibu hamil sehingga menganjurkan ibu untuk mengkonsumsi air tebu dikombinasikan dengan air jahe untuk menetralisirkan mual dan muntah pada ibu hamil dan tebu mengandung glukosa untuk penekanan asam didalam lambung dan dapat mengurangi mual muntah.

\section{KESIMPULAN}

Asuhan yang diberikan pada Ny. P dengan emesis gravidarum yaitu dengan pemberian terapi air tebu dan rebusan jahe untuk menetralisirkan mual muntah yang dilakukan selama 4 hari, dihari pertama ibu masih mual muntah lebih dari 3 kali/hari dan setelah minum terapi air tebu dikombinasikan air rebusan jahe dikunjungan kedua pada hari keempat setelah minum terapi tersebut ibu mengatakan mual muntahnya sudah mulai berkurang menjadi $2 \mathrm{kali} / \mathrm{hari}$. Jadi dapat disimpulkan bahwa air tebu dikombinasikan dengan air rebusan jahe dapat mengurangi mual muntah pada ibu hamil. 
SARAN

a. Diharapkan kepada penyedia layanan kesehatan yang sedang menjalankan praktik untuk bisa menyediakan kelas ibu hamil

b. Diharapkan PMB terhadap pelayanan pada ibu hamil yang mengalami emesis gravidarum dan agar dapat menyediakan leaflet atau brosur agar ibu hamil bisa membaca tentang emesis gravidarum tersebut.

\section{DAFTAR PUSTAKA}

Manuaba, I. A. C. (2010). Buku Ajar Penuntun Kuliah Ginekologi. TIM.

Maulana, H. D. . (2013). Promosi Kesehatan. Penerbit Buku Kedokteran , EGC.

Megasari, M., Yanti, J. S., Triana, A., \& Maita, L. (2019). Catatan Soap Sebagai Dokumentasi Legal Dalam Praktik Kebidanan (Metha \& P.
Desristanto (Eds.)). Nuha Medika.

Notoatmodjo, S. (2010). Promosi Kesehatan:Teori \& Aplikasi. Rineka Cipta.

Pudiastuti, R. D. (2012). Asuhan Kebidanan Pada Ibu Hamil Normal Dan Patologis. Nuha Medika.

Rahmawati, E. N. (2011). Ilmu Praktis Kebidanan. Victory Inti Cipta.

Redi Aryanta, I. W. (2019). Manfaat Jahe Untuk Kesehatan. Widya Kesehatan.

Who. (2015). Reduction Of Maternal $\begin{array}{ll}\text { Mortality. A } & \text { Aoint } \\ \text { Who/Unfpa/Unicef/World } & \text { Bank } \\ \text { Statement. } & \end{array}$ 